\title{
IAMJ
}

INTERNATIONAL

AYURVEDIC

MEDICAL JOURNAL

Review Article

ISSN: 2320-5091

Impact Factor: 6.719

\section{UNDERSTANDING THE THERAPEUTIC AND PHARMACOLOGICAL EFFECTS OF COMMI-PHORA MUKUL (GUGGULU): A CRITICAL REVIEW}

\author{
Sonam Sain ${ }^{1}$, Sangeeta Saini ${ }^{2}$, Suvitha S.V ${ }^{3}$, Nilkanth Upadhyaya ${ }^{4}$ \\ ${ }^{1} \mathrm{PG}$ scholar, PG department of Kriya Sharir, National Institute of Ayurveda, Jaipur, Rajasthan, India \\ ${ }^{2} \mathrm{PG}$ scholar, PG department of Kriya Sharir, National Institute of Ayurveda, Jaipur, Rajasthan, India \\ ${ }^{3}$ PG scholar, PG department of Kriya Sharir, National Institute of Ayurveda, Jaipur, Rajasthan, India \\ ${ }^{4} \mathrm{PG}$ scholar, PG department of Kriya Sharir, National Institute of Ayurveda, Jaipur, Rajasthan, India
}

Corresponding Author: ashvisingh9495@gmail.com

\section{https:// doi.org/10.46607/iamj2009112021}

(Published Online: November 2021)

Open Access

(C) International Ayurvedic Medical Journal, India

Article Received: 07/10//2021 - Peer Reviewed: 26/10/2021 - Accepted for Publication: 31/10/2021

\section{Check for updates}

\section{ABSTRACT}

Guggulu has been a key element in the ancient Indian Ayurvedic system of medication. It has been used extensively by Ayurvedic Acharya for thousands of years to treat a large variety of disorders, besides its use in the pharmaceutical and perfume industries. Guggulu is a gum or resin extracted from the plant Commiphora mukul or Guggulu tree. Guggulu is a shrub or small tree belonging to Burseraceae family. a small perennial tree or shrub up to 1.2-1.8 m high, occurring in rocky tracts of Rajasthan, Barar, Khandesh, Maisoor, Kathiyabad, Belari. Exudate is collected during the winter season by making the incisions in the bark or summer, falling from the bark itself ${ }^{1}$. Guggulu has 5 types that are- Mahishaksha, Mahaneel, Kumuda, Padma, Hiranya. Guggulu is Vishad (nonunctuous), Tikta (bitter), Ushna Virya (hot in potency), increases Pitta, Sara (laxative), Kashaya (astringent), Katu (pungent) in taste, Katu in Vipak (pungent after digestion), Ruksha (causes dryness) and Laghu (light). Chemical compositions of Guggulu are volatile oil, resins and gum, Guggul sterole, Z-guggul sterone, E-guggul sterol-I, II and III, Sesasmine, Cholesterol, Mukolol and other steroids. It has Shothhar, Vedanasthapan, Vranshothan, Vranaropan and Jantughna effects. It uses as an external application in Aamvata, Katishul and Sandhishul.

Keywords: Aamvata, Commiphora mukul, Guggulu, Kushtharoga, Sopha, Medoroga 


\section{INTRODUCTION}

Ayurveda is one of the great gifts of the Acharya of ancient India to mankind. It is one of the oldest scientific traditional medical systems in India and is considered as most holy, excellent system honoured by those proficient in the Veda. Knowledge about the healing property of plants and formulations used in Ayurvedic therapeutics mentioned in classics are a result of conversant clinical observations made over centuries. Details about their properties and therapeutic applications are available in ancient scriptures like Veda, Samhita, and Purana. Compilations of later periods that are called Nighantus also contain an enormous amount of information. The current worldwide trend towards utilization of plantderived natural remedies has, therefore, created a dire need for accurate and up-to-date information on the properties and uses, efficacy, safety, and quality of medicinal plant products. Guggulu preparations are considered an ancient Indian Ayurveda system of medicine. It has been used widely by Ayurveda physicians for long years to treat a different variety of disorders. It is a popular herb classified as Tridoshghna in Indian Ayurvedic medicine that is used to treat several disorders ${ }^{2}$. Guggulu is exudate obtained in the form of oleo gum resin from the stem of the plant Commiphora Mukul belongs to the Burseraceae family. It is known to have analgesic, anti-inflammatory activity, etc. So, it's used in various Ayurveda formulations.

Due to its healing properties, it has been used for thousands of years in India to treat a wide range of health conditions. History revealed that Guggulu has a prime place in Atharva Veda. A detailed account of Guggul as a drug is given in the Vrahat Samhita like Charaka, Sushruta, Vagbhata, and various Nighantu written in India. Guggulu always formulated with other ingredients in formulation-based concept in Ayurveda with or without specific Anupana. Since reviewing Guggulu and its Ayurvedic classical preparations along with Anupana mentioned in classics were not available on one platform. In this review article tremendous effort was made to compile the details of Guggulu and its Ayurvedic formulations in the Ayurvedic System of Medicines along with its therapeutic uses.

\section{Materials}

A comprehensive review has been made through Ayurvedic Samhita, Rasagrantha, Sangraha Grantha, and Nighantu. Views of their critics, as well as contemporaries, were also taken into consideration for the compilation of Guggulu. The journals, webpage and modern books were also screened during the review attempt on Guggulu and its therapeutics importance.

\section{SYNONYMS}

\begin{tabular}{|l|l|}
\hline Sanskrit & Purah, Devdhoop, Jataayu, Mahishaksha, Kaushika, Palankash, Kumbholookhalak \\
\hline Assamese & Guggul \\
\hline Bengali & Guggula \\
\hline English & Gum-gugul, Indian Bdellium \\
\hline Gujrati & Gugal, Guggal, Gugar \\
\hline Hindi & Guggul \\
\hline Kannada & Kanthagana, Guggala, Mahishaksha Guggulu, Guggulugida, Guggulu, Guggal \\
\hline Kashmiri & Guggul Dhoop, Kanth Gan \\
\hline Malayalam & Gulgulu, Guggulu \\
\hline Marathi & Guggul, Mahishaksh \\
\hline Oriya & Guggulu \\
\hline Guggal & Guggal \\
\hline Tamil & Mahisaksi Guggalu \\
\hline Telugu & Makishakshi Guggulu, Guggipannu \\
\hline Urdu & Muqil (Shihappu) \\
\hline
\end{tabular}




\section{Classification $^{4}$}

\begin{tabular}{|l|l|}
\hline Kingdom & Plantae \\
\hline Subkingdom & Tracheobionta \\
\hline Division & Magnoliophyta \\
\hline Class & Spermatopsida \\
\hline Sub Class & Maqnoliidae \\
\hline Order & Sapindales \\
\hline Family & Burseraceae \\
\hline Genus & Commiphora \\
\hline Species & Mukul \\
\hline
\end{tabular}

\section{Type of Guggulu}

There are 5 types of Guggulu include -

\begin{tabular}{|c|l|l|l|}
\hline S. No. & Type & Description & Uses \\
\hline 1. & Mahishaksha & $\begin{array}{l}\text { Mahishaksha has the colour of honeybee or } \\
\text { Anjana } \text { (antimony sulphide) }\end{array}$ & Useful in elephant's disease \\
\hline 2. & Mahaneel & $\begin{array}{l}\text { Mahanila is similar to its name and looks like a } \\
\text { Sapphire, a precious stone. }\end{array}$ & Useful in elephant's disease \\
\hline 3. & Kumuda & $\begin{array}{l}\text { Kumuda resembles Kumuda flower (white) in } \\
\text { colour. }\end{array}$ & Useful in horse's disease \\
\hline 4. & Padma & Padma resembles Manikya (ruby red). & Useful in horse's disease \\
\hline 5. & Hiranya & Hiranya is like gold in colour. & Useful in human being's disease \\
\hline
\end{tabular}

The other two varieties of the Guggulu have been mentioned in the textbooks of Ayurveda:

\section{1). Nava Guggulu}

\section{2). Purana Guggulu}

The freshly collected Guggulu is a tissue builder and aphrodisiac and if stored for more than one year, it is depletory of tissues. The characters of fresh Guggulu are oily, yellowish look like a ripen Jambu fruit, fragrant and gummy. Purana or old decayed Guggulu is dry, emitting bad smell, devoid of natural colour and potency 5 .

\section{DESCRIPTION}

\section{a) Macroscopic}

The Guggulu plant is bushy whose thick spreading branches have thorny tips. The Height of the Guggulu plant is about 4-8 feet. The wood is white and soft. Leaves have 1 to 3 leaflets, conical above, tooth-like in the front, smooth, shiny, and usually at the ends of small thick branches. the bark is yellow with a green touch. Flowers are small and brownishred in colour with 4-5 petals. Fruits are small, fleshy, elongated, and red when ripe.
Drug occurs in vermicular or stalactitical pieces of pale yellow or brown coloured mass, makes milky emulsion in hot water and readily burns, when fresh viscid and golden coloured, odour, aromatic, taste, bitter and astringent. ${ }^{6}$

\section{b) Microscopic}

\section{IDENTITY, PURITY AND STRENGTH}

- Foreign matter Not more than 4 percent.

- Total Ash Not more than 5 percent.

- Acid-insoluble ash Not more than 1 per cent.

- Alcohol-soluble extractive is Not less than 27 percent.

- Water-soluble extractive is Not less than 53 percent.

- Volatile oil Not less than 1 percent $^{7}$

Chemical composition- Volatile oil, resins and gum. Guggul sterole, Z-guggul sterone, E-guggul sterol-I, II and III, sesasmine, cholesterol, mukolol and other steroids.

Habitat- Desert areas of Rajasthan, Gujarat and also cultivated in Mysore, Deccan and other parts of India. 
PROPERTIES AND ACTION

\begin{tabular}{|l|l|}
\hline Rasa Panchak & Description \\
\hline Rasa & Tikta, Katu \\
\hline Guna & $\begin{array}{l}\text { Laghu, Ruksha, Tikshna, Vishad, Sukshma, Sara, Sugandhi (Purana Guggulu), Snigdh, Picchala } \\
\text { (Naveen Guggulu) }\end{array}$ \\
\hline Virya & Ushna \\
\hline Vipaka & Katu \\
\hline Karma & Balya, Rasayana, Varnya, Vitabal;sajit, Bhagnasandhanaka Medohara \\
\hline Prabhav & Tridoshar \\
\hline
\end{tabular}

According to Bhavprakash Nighantu, Ayurvedic properties of Guggulu are: - Guggulu is Vishada (nonunctuous), Tikta (bitter), Ushna Virya (hot in potency), increases Pitta, Sara (laxative), Kashaya (astringent), Katu (pungent) in taste, Katu in Vipaka (pungent after digestion), Ruksha (causes dryness) and Laghu (light). Guggulu is Bhagna-sandhankrid (Unifies fracture), Vrishya (aphrodisiac), Sukshma (enters into minute pores), Swarya (improves voice), Rasayana (rejuvenative), Dipana (appetizer), Balya, mitigates Kapha and Vata, cures Apachi, Medoroga, Meha, Ashmari, diseases of Vata, Pidika, Granthi, Shoph, Arsha, Gandamala, Krimiroga. It mitigates Vata by its Madhuraya (sweet taste), Pitta by its Kashayatva (astringent taste) and Kapha by its Tiktatvata (bitter taste), so Guggulu mitigates all the Doshas.

IMPORTANT FORMULATIONS - Vataari Guggulu, Yogaraja Guggulu, Simhanada Guggulu, Kaisora Guggulu, Mahayogaraja Guggulu, Chandraprabha Vati ${ }^{8}$, Navak Guggulu, Medohar Guggulu

THERAPEUTIC USES - Aamvata, Kushtha, Prameha, Vatavyadhi, Granthi, Sopha, Gandamala, Medoroga $a^{9}$ Doshakarma- Guggulu said to be Vatashamak due to its Ushna property. It is the main drug among Vatashamak drugs. It has Medohara effect due to Ruksha and Vishad Guna so that it is very beneficial in Medavrat Vata. Guggulu has Kaphashamak effect due to Tikshna and Ushna Guna. Systemic function- External use

It has Shothahara, Vedanasthapana, Vranshothaghna, Vranaropana and Jantughna effects. It uses as an external application in Aamvata, Katishula and Sandhishula.

\section{Internal use-}

1. Nervous system disorders - Because of its Vatashamak property, it has the Vedanasthapak effect and provides strength to nerves. Kaishora Guggulu is very beneficial in Angaghat, Ardita, Urustambha,

and Vatanadi Shulah. In Urustambha It is given with Gomutra, and in Gridhrasi it is given with Rasna and Ghrita. Guggulu has a good effect on Aamvata (Rheumatoid Arthritis) Arthritis is mainly caused due to inflammation of joints, the tissues surrounding the joints, and other connective tissues. Osteoarthritis is the most common form of arthritis which affects a wide range of people across all places. As Guggul has been reported to exhibit high affectivity against arthritis pre-clinically; hence, its effect was evaluated in the clinical setting as well.

2. Digestive system disorders - Due to its Katu Tikta and Sukshma property, it has a Deepan effect. Due to Snigdh, Sara property it has Anuloman and Pittasarak effects. Due to Tikta and Ushna Guna, it has Yakrituttejak, Arshoghna, and Kramighna effects. Due to Sugandhi Guna Guggulu removing Koshthagat bad odour. Guggulu improves appetite and digestion, because of this property it is used in gastric dysfunction. It is given as an intestinal antiseptic in Atisaara, Pravahika, Antrapradah, and Kshayaj Atisaara with Sugandhi Dravya, Indrayava, Elua, and jaggery. It has a greater effect on women than on men.

3. Cardiovascular system disorders - it has a good effect on the heart, increase the number of RBC 
and WBC, purifies the blood. It has Sothhar and Gandamalanashak effects also.

4. Respiratory system disorders - it reduces Kapha Dosha, so it is used in chronic Kapha Roga, Swash Roga, and the condition of Kshaya. In chronic Kapha Roga, it is given with Chhoti Peepal (Piper longum), Adusa (Justicia adhatoda) honey, and ghee. In Rajayakshma it uses as reduces the amount of Kapha and also kills the bacteria. Diseases in which Kapha is excessive and sticky, it is used widely. It is beneficial in many conditions like Swaryantrasotha, Swashni-Sotha, Jalodar, Kanthmala. Guggulu has given along with Parad, Soma, and Vaividang in Kanthamala.

5. Urinary system disorders- Guggulu crushes stone and remove turbidity present in the urine, because of this property it is used in urinary system disorders like Ashmari, Mutrakrichchha, Pooymeha. Guggulu improves appetite and digestion, because of this property it is used in gastric dysfunction.

6. Genital organ disorders -, Guggulu is widely used in Shukra-Daurbalya (oligospermia), Klaibya (infertility). Guggulu has a good effect on the uterus Kashtaartava (dysmenorrhea), and other Yoni-vyapada (genital organ disorders). In young females who have developed amenorrhoea, it is used along with Ghritkumari and Kasisa in tablet form.

7. Skin disorders Guggulu is useful in all types of Charma Roga. It reduces itching and increases the complexion of the skin, so it is used in pigmentary disorders.

Guna and Prayoga Guggulu has Rasayan, Tridoshaghna, Vrishya, Valya, Snehan, Sansrasan, Vatanulomak, Am-ashyottejak, Deepan, Vatahara effects, strengthen and stimulate the nervous system, cough expectorant, stimulate mucosal layer, have constricting and antiseptic effects.

Contraindications - Food items that contain Amla Rasa, Tikshna Guna, Ajeernakarak Dravya, sexual intercourse, hard work, sunlight, alcohol consumption, and anger should be avoided while consumed Guggulu.
Aamyik Prayog ${ }^{10}$

- Vata-Kapha nashak and Tridoshanashak

- Vranya, Swarya Sansrasan, Agnideepan

- Rasayan, Kleda, Meda, Shothhara

- Pidika, Granthi, Apachi, Vrana, Gandamala Nashak

- Krami and Prameha Nashak

Examination of Guggulu - It should be a shiny, sticky, pleasant odour, yellowish (fresh), blackish (old), bitter in taste, and easily fragile. It should be Green and reddish from inside on breaking. While rub in hot water glossy white colour mixture is formed. It doesn't burn well when it is lit. Business people sell burnt wood by making balls by applying many types of sticky gum, so it should be bought after doing a good test. Always use fresh Guggulu, because keeping it for long spoils its properties. ${ }^{11}$

Purification- Take Triphala and Guduchi equal to Guggulu and grind them coarsely and prepare decoction in Ashtaguna water. After filtering the decoction with cloth, tie Guggulu in a cloth and hang above the decoction, then sweat it on low flame. Repeatedly putting that decoction on the bundle with a ladle, when all the Guggulu filters come in handy, then throw the dirt in the cloth and take out the Kwath from top to top. Set aside the frozen condensed mang at the bottom. Cook the Guggulu mixed Kwath on low flame. When it starts to thicken, put some ghee in it so that it does not burn. After that, grind it very well and keep it on top of ghee, although it is customary to do purification by this method, however, Guggulu may have become somewhat humbled by this method because modern Ayurvedic Acharyas have the opinion that the properties of Guggulu depend especially on the aromatic elements in it. That's why only after boning the Guggulu very well, adding ghee to it and then treating it with a lot of cracking can be more appropriate. Some people also do milk or Dashmool work in place of Triphala Kadha. ${ }^{12}$

Parts Used - Gum- resin ${ }^{13}$

DOSE - 2- 4 gm of the drug ${ }^{14}$ 


\section{CONCLUSION}

In this review article, it is concluded that Guggulu is one of the oldest and most famous drugs in Ayurvedic medicine. Guggulu is a multi-purpose drug and because of its incredible properties, it is very beneficial in so many diseases. Guggulu has several uses which are supported by various researches done by researchers throughout the world. These findings could open a new window on the use of this plant in Ayurveda. Due to its Ushna Veerya, heat is felt in the stomach after its consumption. Its absorption is very fast. Its properties probably depend on the aroma content in it. It is excreted from the skin, mucosal membrane, and kidneys, and at the time of excretion, it stimulates those organs and also acts as a bactericidal. It can be used for many days without any side effects. It is used in chronic Kapha Roga, Vataroga, numbness, Gradhasi, Ardita, Agnimandhya,

Apachan, Kanthamala, Granthi, Vidradi, Kushtha, Firanga (syphilis) Sujaak (Gonorrhoea), Sotha of different organs, Shopha, Udara Roga, Charma Roga, Vrana, Bhagandar, Krami Roga, Pandu, Arsh, Prameha, Garbhashaya Vikara and Medovraddhi with those intended drugs acting on those organs.

\section{REFERENCES}

1. The Ayurvedic Pharmacopoeia of India Government of India Ministry Of Health And Family Welfare Department Of Ayush Part- I Volume - I Formulation 28 Page No. 56 - 57

2. Dravyaguna Hastamalak By Vaidya Banwari Lal Misra Published by Publication Scheme Edition In 2005

3. Bhavprakash Nighantu Of Shree Bhavamishra Edited by Pandit Shree Brahma Sankara Mishra Vol. 1 Published by Chaukhambha Sanskrit Sansthan Varanasi Gana Karpuradi Page No. 206

4. Https://En.Wikipedia.Org/Wiki/Commiphora_Wightii

5. Singh, D., Dhyani, S., \& Kaur, G. (2015). A Critical Review on Guggulu [Commiphora Wightii (Arn.) Bhand.] \& Its Miraculous Medicinal Uses. International Journal of Ayurveda And Pharma Research, 3(1). Retrieved From Https://Ijapr.In/Index.Php/Ijapr/Article/View/168
6. The Ayurvedic Pharmacopoeia of India Government Of India Ministry Of Health And Family Welfare Department Of Ayush Part- I Volume - I Formulation 28 Page No. 56 - 57

7. The Ayurvedic Pharmacopoeia of India Government Of India Ministry Of Health And Family Welfare Department Of Ayush Part- I Volume - I Formulation 28 Page No. 56 - 57

8. The Ayurvedic Pharmacopoeia of India Government Of India Ministry Of Health And Family Welfare Department Of Ayush Part- I Volume - I Formulation 28 Page No. 56 - 57

9. The Ayurvedic Pharmacopoeia of India Government Of India Ministry Of Health And Family Welfare Department Of Ayush Part- I Volume - I Formulation 28 Page No. 56 - 57

10. Madanpal Nighantu Written by Prof. Gyanendra Pandey Published By Chaukhambha Orientalia Varanasi Edition 2012

11. Bhavprakash Nighantu Of Shree Bhavamishra Edited by Pandit Shree Brahma Sankara Mishra Vol. 1 Published By Chaukhambha Sanskrit Sansthan Varanasi Gana Karpuradi Page No. 206

12. Bhavprakash Nighantu Of Shree Bhavamishra Edited by Pandit Shree Brahma Sankara Mishra Vol. 1 Published By Chaukhambha Sanskrit Sansthan Varanasi Gana Karpuradi Page No. 206

13. A Handbook Of Dravya Guna By Prof. J.K. Ojha

14. Dravyaguna Vigyana Vol 2 By P.V. Sharma Published by Chaukhamba Bharti Academy Edition 2013

\section{Source of Support: Nil Conflict of Interest: None Declared}

How to cite this URL: Sonam Sain et al: Understanding The Therapeutic And Pharmacological Effects Of Commi-Phora Mukul (Guggulu): A Critical Review. International Ayurvedic Medical Journal \{online\} 2021 \{cited November 2021\} Available from: http://www.iamj.in/posts/images/upload/2769_2774.pdf 